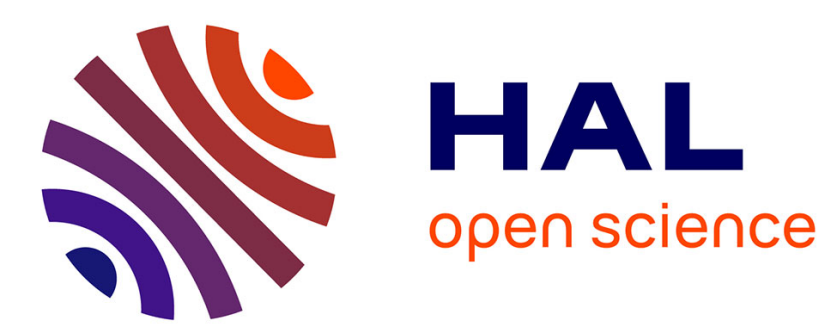

\title{
Aspects of the transitory deformations correlated with the cracking at heat in welding
}

\author{
V. Miclosi, Gh. Solomon, I. Tonoiu
}

\section{To cite this version:}

V. Miclosi, Gh. Solomon, I. Tonoiu. Aspects of the transitory deformations correlated with the cracking at heat in welding. Journal de Physique IV Proceedings, 1993, 03 (C7), pp.C7-1087-C7-1091. 10.1051/jp4:19937170 . jpa-00251800

\section{HAL Id: jpa-00251800 https://hal.science/jpa-00251800}

Submitted on 1 Jan 1993

HAL is a multi-disciplinary open access archive for the deposit and dissemination of scientific research documents, whether they are published or not. The documents may come from teaching and research institutions in France or abroad, or from public or private research centers.
L'archive ouverte pluridisciplinaire HAL, est destinée au dépôt et à la diffusion de documents scientifiques de niveau recherche, publiés ou non, émanant des établissements d'enseignement et de recherche français ou étrangers, des laboratoires publics ou privés. 


\title{
Aspects of the transitory deformations correlated with the cracking at heat in welding
}

\author{
V. MICLOSI, Gh. SOLOMON and I. TONOIU
}

Polytechnic Institute of Bucharest, 313, Sp. Independentei, Fac. I.M.S.T., Cat. T.M.S., 77206 Bucarest, Romania

\begin{abstract}
The cracking at heat is one of the main problems which appear at the austenitic steel welding, especially for the austenitics steel without deltio ferite.

The susceptibility regarding the cracking at heat can be studied analiticaly by the correlation between two factors the factor stress constitued by the tension and the deformations which appear in the welding process (FS) and the resistance factor constitued by the capacity of the material to take the stress and the deformatons appeared (FR).

As a result of the interaction of the both factors is the posibility of cracking or not cracking into a concret case, named generaly the sueceptibility at the heat cracking.

The tendency at the cracking at heat con be apreciate with a quantitativ estimation, named critical speed of cracking (vof). The practical determination of these speed suposed for an concret exemple, the knowledge of real plastic deformation at the weld, which are determinated in this paper.
\end{abstract}

\section{TRANSITORY DEFORMATION AT THE HELDING}

The transitory stress and deformations in the weldirg process are represented by the stress and deformations which waried in time along the operation of welding in accondance with the termic cycles.

On the point of one on the cracking at heat that is intresting are the transitory deformations which are manifested on the high temperatures, at the solidificition interyal for the stepls considerated and less under the solidus point, on the heat iragilisation interwal (IFT). 
For the main aspects about the appearance of the welding transitory deformations, we'l consider the case of the precipitete of ane row on a plate; in the situation when we andise only the stress (Sy) and we don't analyse the three-dimensional tensions field. The themic field form is presented in Fig. 1.

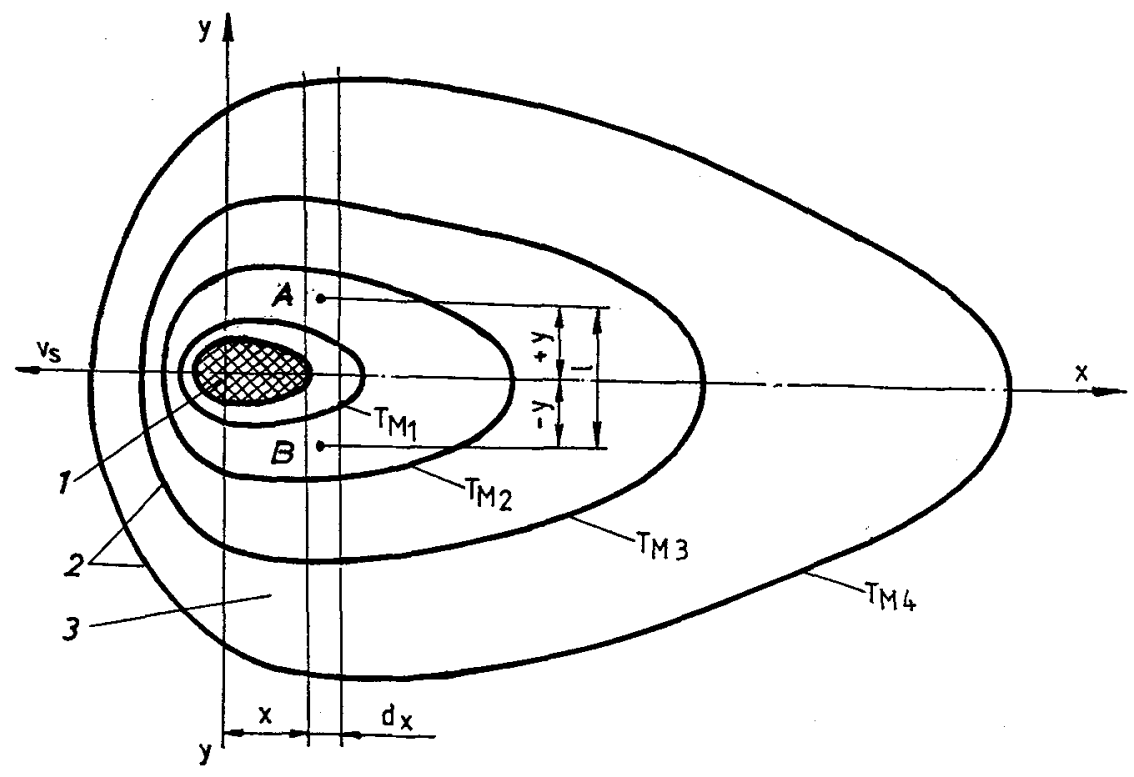

Fig. The thermic field form at the deposit of one row on a plate:

1-The liquid metal bath, resulted after the mouvement of the electric orch displacement with the welding speed, Vs;

2-Maximum temperature izotherm (TM);

3-Thin material strip, breadth dx;

$A B$ is measuring base, length l=2yo.

Considerring, as initial moment, that when liquid metal bath (1) leaves the thin material strip (dx), the temperature equalization process begins, thanks to the conduction to the colder parts of the plate and thanks to the reat elimination in the ambient average.

In this case, supposing like acquainted the temperature functions yariation in time, the elosto-plastic real deformation of the measuring base $A E$ is given by the relation:

$E p(T)=E t(T)-E m(T)$.

Et(T)-themic relative deformation of $\mathrm{AB}$ tose.

Emit)-measured relative deformation of $A$ E base. 
The practical application deficiency of this relation consists in experimental determination of the measured relative deformation. Considering this, we conceived a determination experiment of this deformstion.

THE EXPERIMENTAL DETERMINATION OF THE RELATIVE MEASURED TRANSITIONAL DEFORHATIOH

On an austenitic stegl plate, type 10 TiMicr $180,300 \% 150 \times 6 \mathrm{~mm}$. were positioned wolfram electrodes, resulting the assembly presented in the Fig. 2.
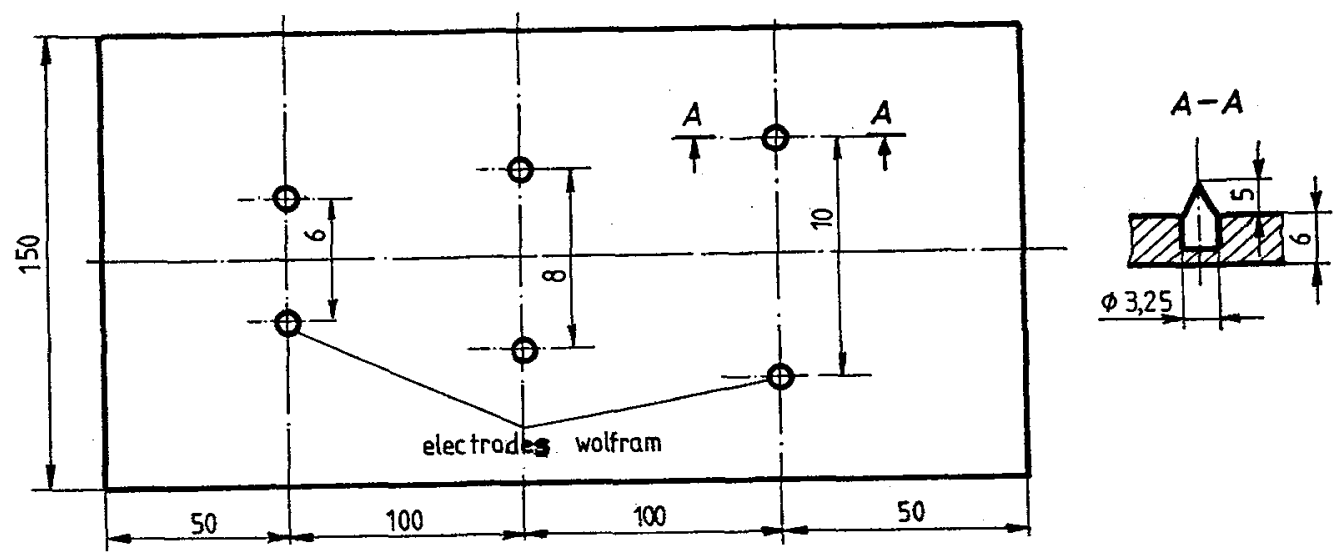

Fig.2. The elements of the test used to determine $8 \mathrm{~m}(\mathrm{~T})$

The presented assay was fiked into a dewice and a welding cable was met on the axis of the plate, from the leit to the right, interwal during which it was filmed and photographed ultrariapidely the variation of the distance between the wolfram electrodes. The photography was taken before the beginning of the welding process and afer the electric arch left the section where the wolfram electrodes were planted, the electric arch being screened by a sceen.

The measurements realised on slides, based on these photos, are shown in the Table 1. 
Table 1.

\begin{tabular}{|c|cccc|}
\hline $\begin{array}{c}\text { Time } \\
\text { basis for the steel } \\
\text { loTinicr180, mm }\end{array}$ & $\begin{array}{c}\text { Values of the measurement } \\
\text { basis for the steel } \\
\text { oL } 37.2 \mathrm{~K}, \mathrm{~mm}\end{array}$ \\
\hline 0 & & $8 \mathrm{~m}(\mathrm{~T})$ & & $\mathrm{Em}(\mathrm{T})$ \\
2 & 6 & 0 & 5,87 & 0 \\
4 & 5,9 & 0,016 & 5,812 & 0,01 \\
6 & 5,837 & 0,027 & 5,775 & 0,017 \\
8 & 5,812 & 0,031 & 5,725 & 0,025 \\
10 & 5,775 & 0,047 & 5,687 & 0,032 \\
\hline
\end{tabular}

\section{CONCLUSIONS}

Analising the resuls of the Tablel we con stress the following:

1) The value of the deformation messured in the case of the sample in carbon steel, stressing the influence af different dilation coeficients of the two materials.

2) The values of the deformation, measured in the temperature interval which presents interest from the point of wew of the crocking at heat $(1300-700)$ are of an order of some tenth of percentage, according to the speciality literature.

3) Given the conditions of the deteminations, we can state that the values of the meseured transtorial deformations are close to the themic transitorial deformitions in the considered thermic interyal.

4The experimental model we used does nat correspond to the most practical situations of welding. where the phenomena are much more complex, but is demonstrates the posibility of practical detemination of the measured transitorial deformations.

5) Although the considered transitorial deformations are relatively small comparatively to the extent of the deformations detamining the cracking at heat, these can determine the cracking, because the transitorial plastic deformation can not be uniformely distributed on a measurement basis of about $6 \mathrm{~mm}$, very great comparatively with the lenght of the zone where the material is in the interval IFT $(0,5-1 \mathrm{~mm})$. 
Admitting that the plastical deformation st a macroscopic scale is unevenly distributed, we obtain for regl transitoriel plastic deformations values of 6-12 times greater than the mentioned walues and which are able to determine the cracking at heat.

\section{REFERENCES}

1. Welding metalurgy of stainless sted, E. Folkhart, New York 1968; 2.Cracking in the transwarestraint test, E.F. Dixon, R.H.Fhilips; \& JCRitter, Metal Construction 1994: 